\title{
Sharia and Moon Sighting and Calculation Examining Moon Sighting Controversy in Nigeria
}

\author{
Abdulmajeed Bolade Hassan-Bello \\ University of Uyo - Nigeria \\ email: boladebello@yahoo.com
}

\begin{abstract}
s
This paper aims to explain the problem of new moon confirmation which is a severe problem in Nigeria. Besides, this paper also offers solutions to solve these problems. Information and data are obtained through tracking literature and then analyzing it. Global and regional appearances are debatable among scholars. Still, they agree in terms of the start of the month of Ramadān which depends on the physical appearance of the crescent moon or the completion of the month Sha'bān s30 days. This paper concludes that Muslims accept Science and Technology to be used to help see the new moon as a compliment, not as an alternative. However, the controversy over the sighting of the moon in Nigeria is not particularly religious, so it will continue as long as the country continues its religious politics and religious politics.
\end{abstract}

Keywords: 'Arafah day; Eid al-Adha; global moon sighting; moon sighting; regional moon sighting physical

Tulisan ini bertujuan untuk menjelaskan masalah konfirmasi hilal yang merupakan masalah serius di Nigeria. Salain itu, tulisan ini juga menawarkan solusi memecahkan masalah tersebut. Informasi dan data diperoleh melalui pelacakan literatur kemudian menganalisisnya. Penampakan global dan regional menjadi perdebatan di antara pada sarjana, namun mereka sekata dalam hal permulaan bulan Ramad̄an yang tergantung pada penampakan fisik bulan sabit atau sempurnanya bulan Sha'bān s30 hari. Tulisan ini menyimpulkan bahwa Muslim menerima Sains dan Teknologi untuk digunakan dalam membantu melihat bulan baru sebagai pelengkap, bukan sebagai alternatif. Namun, kontroversi tentang penampakan bulan di Nigeria tidak terlalu bersifat religius, sehingga akan terus berlanjut selama negara tersebut melanjutkan politik agama dan politikagama.

Kata Kunci: hari Arafah; Idul Adha; global moon sighting; moon sighting; regional moon sighting physical 
Abdulmajeed Bolade Hassan-Bello

\section{Introduction}

In the classical Arabic language, the word "crescent" (hilāl) is defined as, "the first light of the moon, when people see the crescent at the outset of a month."1 "Hiläl (crescent) is the initial light of the moon that appears up until three days." 2 Thus, "hilāl" (Crescent) denotes, "the moon specifically on the first and second night"; after that, it is simply called "moon" (qamar).3 "The crescent was born" (halla-yahillu-hilāl) means "it appeared", the crescent, therefore, is "the new moon when people see it."4 The crescent moon is something that is seen. It is a physical phenomenon that upon seeing it people tend "to cry for joy," halla, which means "to appear; to begin to shine, as the new moon; to exclaim; to exult; to sing; to rejoice; to praise or worship God." 5

The debate over confirming the hilall is an old one dating back to the second century of the Islamic era. The debate intensified in the second half of the last century as many Muslim scholars became concerned about the inconsistency of sighting reports and the fragmentation of Muslim communities over the determination of the first day of Ramadiann and the two Eids. The controversy is on whether establishing the start and end of the lunar months through physical moon sighting the only valid opinion or use of Astronomical Calculations as an alternative is valid in Islamic Jurisprudence is the bone of contention. ${ }^{6}$ However, the debate over the determination of the birth of the new crescent (hilāl) has taken a new urgency in North America after the Fiqh Council of North America (FCNA) announced, the use of calculation for establishing the beginning of the Islamic lunar month. The ruling established astronomical calculations as the sole criteria for deciding the birth of the new crescent. Thus for the first time, we come face to face with the

${ }^{1}$ Al-Khalīl ibn Ahmad al-Farāhīdī, Kitāb al-'Ayn, vol. IV (Beirūt: Dār Al-Kutub Al-'Ilmiyyah, 2003), 320.

2 Ismāîl Ḥaqqī al-Barūsuwī, Tanwīr al-Adhhān min Tafsìr Rūh al-Bayān, vol. I (Damascus: Dār alQalam, 1988), 148.

${ }^{3}$ Abū al-Qāsim al-Ḥusain al-Rāghìb al-Iṣfaḥanī, al-Mufradāt fi Gharīb al-Qur'ān (Damascus: Dār alQalam, 1992), 843.

${ }^{4}$ Muhammad Ibn Mukram Ibn Manẓūr, Lissan al-'Arab, vol. II (Beirūt: Dār al-Kutub al-'Ilmiyyah, 1993), 693.

5 Hamza Yusuf, 'Cesarean Moon Births', n.d.

${ }^{6}$ Omar El-Banna, 'Moon Sighting Explained', n.d. 
prospect of confirming the beginning of Ramaḍann and Eids without the recurring hassle and flare. ${ }^{7}$

The debate over how the new Islamic lunar month is to be decided transcends beyond just that of a debate in favour of one method over the other, and the transition from moon sighting to the astronomical calculation is more than a transition from one juristic (figh) position to another. The debate is, indeed, about how to read Islamic sources, and how to relate Islamic precepts to contemporary society. The transition is about the ability of contemporary Muslim scholars to reclaim the authority of independent judgment (ijtihād) truly, and hence build on the knowledge and achievements of early scholarship to reach better-grounded consensus (ijmā ). ${ }^{8}$ FCNA's ruling in favour of using the astronomical calculation for determining the beginning of the Muslim lunar month provoked a strong response, and the American Muslim community continues to be divided over this issue. Scholars on the two sides of the divide present arguments rooted in Islamic traditions, and often support their views by citing the same Qur'anic and Prophetic sources, or by referring to statements by early Muslim scholars. It does not take much for an observer to realize that the division and disagreements are not about the sources themselves, but about the interpretations and rationalizations of those sources. The division is between scholars who emphasize the apparent meaning of the text (zāhir) and those who emphasize its intended meaning and purpose (maqūṣid). ${ }^{9}$

In Nigeria, the issue of moon sighting has been a severe problem of observing the two Muslim Festivals for so many years. It has been a source of controversy among scholars, ('Ulamō') and other members of the society. ${ }^{10}$ The problem includes the fact that despite the official announcement of the sighting of the crescent most Nigerians do not go by the official announcements, and Organized system of monitoring the moon is wanting. Sha'bān and Ramaḍān have had 29 days each in the past 40 years while

\footnotetext{
${ }^{7}$ Louay Safi, 'Reading, Sighting, and Calculating', n.d.

${ }^{8}$ Safi.

${ }^{9}$ Safi.

10 Mustapha Isa Qasim, "The Position of Salatul-Id- Al-Adha in Nigeria on Arafat Day in Saudi Arabia', International Journal for Innovative Research in Multidisciplinary Field 2, no. 11 (2016): 45861.
} 
Shawwāl and Dhūl Qa'dah have had 30 days each but only in Nigeria. Thus, Nigeria leads the world in moon sighting. This has led to a dichotomy, that is, some follow the announcements with absolute loyalty; and those that reject such announcements. Whereas the former maintain that they are following their leaders, as dictated by the Sharia, the latter believe that the leaders are wrong and, therefore, should not be followed. ${ }^{11}$

This paper is an attempt to throw more light on this perennial problem and to offer suggestions based on the views of 'Ulamä' on how to solve the problem. The paper is primarily, sharia study; thus, a prime method for collecting information has been the textual analysis of primary sources of Sharia, the Qur'an, Sunnah and Islamic jurisprudence materials. The opinion of the four famous Sunni schools, namely the Ḥanafī, Mālikī, al-Shāfi'ì and Ḥanbalī are referred to in most cases. Academic works of modern Muslim jurists and thinkers and other journals were also extensively consulted. Thus, the paper is divided into six sections. The first section provides a brief introduction to the paper, and it describes the definition of hilall (crescent). The second examines the Islamic law on Moon Sighting and Calculation. In the third section, the main subject of the paper, i.e., Jurists' opinions on determining the beginning and end of Ramaḍan, and all related matters, is tackled. This includes a thorough discussion concerning the regional sighting, sighting anywhere in a country, a physical sighting anywhere globally, Mecca time-point for reference (as the Hajj is there, and some assert that since anyone wishing to make the pilgrimage must follow Saudi Arabia for the Hajj determination, it logically follows to include Ramadān as well, especially since Saudi Arabia is the only country in the world that still uses a lunar calendar for its day to day scheduling and Astronomical Calculation. The fourth section focuses the controversies on the Moon sighting dilemma in Nigeria. The fifth section deals with the discussion of the subject. The paper is concluded in section six with a conclusion as well as suggestions that cover all the discussion of the preceding five chapters.

11 Usman H Dukku, 'Friday Discourse: The Problem of Moon Sighting in Nigeria: The Way Out', n.d. 


\section{The Islamic law on Moon Sighting and Calculation}

The Qur'an declares that the months with God are twelve lunar months. "Surely the months with God are twelve in the book of God since the day He created the heavens and the earth; four of them are sacred" (Surah al-Tawbah: 36). Al-Nasafi explains the meaning of this verse. He said: "This verse is to clarify that the legal rulings in Sharia are to be determined by lunar months that are calculated by the crescent moons irrespective of the solar calendar."12 Thus, the Qur'an commands Muslims to use the lunar month for their devotional matters, but not necessarily their worldly affairs. Ibn al-'Arabi explains this, commenting on the verse, "They ask you about the crescent moons; say they are a means to measure your specific times (mawäqït) and are also for the commencement of the hajj”"(Surah al-Baqarah: 189). He said: “God has made the sun and moon two of His signs, for two benefits: one worldly, which is the solar calendar, and the other religious, which is based upon the lunar."13

Since two major obligatory acts of devotion and many minor recommended ones have designated times throughout the year, the lunar months have been given to specify those times. The actual word used for "specific times" is mawāqit, and is derived from the Arabic word waqt, which means "time."14 The difference between the word waqt and the other Arabic word for time, zamān, mudda, is that zamān is absolute time mudda, is period, a period; duration ${ }^{15}$ And it refers to the movements of the celestial orbs that indicate it from their starting point to their finishing point. So zamān is the division of time into past, present, and future, whereas waqt is zamān when it specifies a point that is for some specific affair." 16 Thus, the crescent moons were designated for determining specific times within the flow of time. An intriguing aspect of the verse mentioned above is that it was revealed in response to those who asked the Prophet s about the crescents, and they were

\footnotetext{
12 'Abdullāh Ibn Ahmad Al-Nasafi, Tafsīr al-Nasafi, vol. I (Beirūt: Dār al-Qalam al-Ṭayyib, 1998), 678.

${ }^{13}$ Abū Bakr Ibn Al-'Arabī, Aḥkām al-Qur'ān, vol. I (Beirūt: Dār Al-Kutub Al-'Ilmiyyah, 2003), 140.

14 J. Milton Cowan, ed., The Hans Wehr Dictionary of Modern Written Arabic (New Delhi: Modern Language Services, 1994), 1087.

15 Cowan, The Hans Wehr Dictionary of Modern Written Arabic.

16 Muhammad ibn Muștafā Abū Su'ūd, Irshād al-'Aql al-Sālim ilā Mazāyā al-Qur'ān al-Karīm, vol. I (Beirūt: Dār Ihyā’’ al-Turāth al-'Arabī, 1994), 203.
} 
seeking to understand the actual mechanism, that is, the science of the crescent. They wanted to know how the moon did what it was doing. However, the Qur'anic response enlightened them that more important than their question of how is why. This is the essential difference between science and religion and is summed up in this one momentous verse of the Qur'an. The verse immediately following their question, and God's reply is, "Do not enter houses through their back doors." Some commentators understood that to mean, "Ask the right question: why not how." The word in English for the month is derived from the moon. The earliest human calendars are lunar, and it was through lunar calendars and the human need to determine time's progression, especially the passage of the year itself, that led to the development of mathematics. This purpose is clearly stated in verse, "It is God who made the sunshine and the moon glow, and determined the lunar phases that you may know the number of years and calculation" (Surah Yūnus: 5).

According to Ibn 'Abbās and others, 'That you may know the number of years and calculation (hisāb),' was interpreted to mean that the mansions (manāzil) of the moon provided man's ability to calculate which phase of the month he was in, thus enabling him to measure his days, given that there are twenty-eight phases of the month determined by the lunar mansions. On the twenty-ninth, the moon disappears for a day or two only to re-emerge as a newborn crescent. However, it also implies that the challenge of measuring time gave the man an impetus to learn and develop mathematics (hisāb) and by extension science. Hence, the sun and the moon following exact courses enabled humanity to follow them and through doing so increase our knowledge of science. ${ }^{17}$

\section{Jurists' Opinions on Determining the Beginning and end of Ramaḍān}

In reality, there are several positions on moon sighting. The most prominent ones include regional sighting, sighting anywhere in a country, a physical sighting anywhere globally, Mecca time-point for reference (as the Hajj is there, and some assert that since anyone wishing to make the pilgrimage must follow Saudi Arabia for the Hajj determination, it logically

17 Yusuf, 'Cesarean Moon Births'. 
follows to include Ramaḍān as well, especially since Saudi Arabia is the only country in the world that still uses a lunar calendar for its day to day schedule. ${ }^{18}$ And Astronomical Calculation.

\section{Regional moon sighting physically}

According to this opinion if the crescent is physically sighted within the boundaries of a particular region, then the lunar month has started. Any reports of sighting that come from outside the boundaries of the region are irrelevant and do not affect the start or end of the month. This is the Mu'tamad Fatwā (the legal ruling of the School) of the Al-Shāfi'i School. al-Nawāwī, the renowned al-Shāfi'i authority, observes:

If the Moon was sighted in a locality and not seen in the others, then the sighting will apply to the close by areas only. There is no difference of opinion regarding this issue. The difference is only regarding the far away areas. There are two known opinions about this matter. The correct of the two opinions is that people are not obligated to go with the sighting of another locality. ${ }^{19}$

Some of the Hanafi jurists such as Al-Zayla'ì and many others have adopted the local sighting (instead of universal sighting) because the sighting confirms the month (of Ramadān). The sighting in one locality cannot be applied upon the other areas with different horizons. It is just like the noon and Sunset timings. The Sunset timings in one locality would not require the Maghrib prayer at the other locality. ${ }^{20}$

Ibn 'Abidin argues that the fact that horizons are different cannot be debated. The difference in the noon and Sunset timings at different localities bring differences. Every second, with the westward movement of the Sun, there is morning for a new locality and evening for some others. ${ }^{21}$ Al-Zayla'i prefers local sighting due to the same reasons. He said:

It is more like to be considered because every people are addressed by what they have. And the separation of the crescent from the sunbeam

\footnotetext{
18 Yusuf.

${ }^{19}$ Abū Zakariyyā Muhyiddīn Yahyyā ibn Sharf al-Nawawī, Al-Majmū’Sharḥ al-Muhadhdhab, vol. VI (Jeddah: Maktabah al-Irshād, n.d.), 280.

20 'Uthmān ibn 'Alī al-Zaylaî, Tabyīn al-Haqāiłq Sharh Kanz al-Daqã̄iq, vol. I (Beirūt: Dār al-Kitāb alIslamī, 2009), 316.

${ }^{21}$ Muhạmmad Āmīn Ibn ‘Ābidīn, Radd al-Mukhtār 'alā Durr al-Mukhtār, vol. III (Riyāḍ: Dār 'Alam al-Kutub, 2003), 363.
} 
varies by different diameters as the entry and exit of time is occupied by different diameters. ${ }^{22}$

The proof for this opinion is the famous hadith of Kurayb who reported that Umm al-Faḍl Binti al-Harīth sent him to Mu'awiya in Al-Sham; he said: "I arrived in Al-Sham and did business for her (Umm al-Faḍl Binti al-Harīth). It was there in Al-Sham that the month of Ramadān commenced. I saw the new moon of Ramadān on Friday. I then came back to Medina at the end of the month. Abdullah Ibn 'Abbās asked me about the new moon of Ramadān and said: "When did you see it?" I said: "We saw it on the night of Friday," He said: "Did you see it yourself?" I said: "Yes, and the people also saw it and observed the fast and Mu'awiya also observed the fast"; after that, he said: "But we saw it on Saturday night, so we will continue to observe fast till we complete thirty (fasts) or we see it (the new moon of Shawwāl)." I said: "Is the sighting of the moon by Mu'awiya not valid for you?" He said: "No, this is how the Prophet has commanded us". ${ }^{23}$ Thus, the report of Kurayb is the indisputable evidence of the local sighting. 24

The argument is based upon the fact that Ibn 'Abbās did not act upon the sighting report from Syria. Ibn 'Abbās, in conclusion, said that this was what the Prophet (PBUH) had commanded us. This proves that the Prophet (PBUH) did not obligate Muslims to go by the sighting report of other localities and that was what Ibn 'Abbās had narrated from the Prophet.25

Scholars who approve of this opinion differed on the criteria that define the boundaries of a particular region. Some scholars thought that the boundaries of a region should depend on the travel distance (82 KM approximately). Others said that what should be considered is the difference in horizons (Ikhtiläf al-Matāli'), thus if two regions usually vary in their sightings of the crescent, then a report of sighting in one of them should not affect the other. The third group of scholars led by Ibn Majshūn, a prominent Mālikī jurist said that regions should depend on the Imam's authority (head of Islamic state) so

\footnotetext{
22 Al-Zaylā̂̀, Tabyīn al-Haqā’iq Sharh Kanz al-Daqāiqq.

23 Muhammad Ibn 'Alī Al-Shawkānī, Nayl al-Awțār, vol. IV (Cairo: Maktabah Dār Turāth, 1965), 194.

24 Zulfiqar Ali Shah, 'The Astronomical Calculations and Ramadan: A Fiqhi Discourse', International Institute of Islamic Thought, 2009.

25 'Abd al-Raḥmān al-'Az̄ịm Abadī, 'Awn al-Ma'būd Sharḥ 'alā Sunan Abī Dāwud (Beirūt: Dār Ibn Hazm, 2005), 1090.
} 
if the Imam announces the start of the lunar month, then all cities under his authority should accept. ${ }^{26}$

\section{Global moon sighting}

The early Hanafī, Mālikī, Hanbalī and some al-Shāfi'î jurists strongly believed in the unity of horizons. They obligated fasting for the entire Ummah in case of actual sighting in any Muslim city or country. They went so far as claiming that the Prophetic commandment itself required such fasting. ${ }^{27}$ Encyclopedia of Fiqh stated:

"According to Hanafí, Mālikī, Huanbalī (and according to one report from the al-Shăfi'i school of thought), no consideration is given to the diversity of horizons in regards to confirming the month of Ramadān. The entire Muslim world is obligated to begin fasting if the new Moon is sighted anywhere in the world. This is in line with the Prophetic tradition "start fasting by seeing the new Moon." The hadīth is addressed to the entire Muslim nation." 28

The common understanding is that according to this opinion, the world is considered as one region. Thus if the crescent is sighted anywhere in the world, all the Muslim Ummah should start the lunar month. This is the Mu'tamad Fatwā in the Ḥanafī, Mālikī, and Hanbalī schools. The renowned Hanafi jurist Al-Nasafi said: "Month of Ramaḍann is established with the sighting of its crescent and different horizons is not considered." 29

Ibn Nujaym from Hanafi School said: "The correct view of our companions is that, if the report of a sighting of the moon is extensive and verified among the people of the other town, all must be abide by the rule of that town".30 'Uthmān Ibn 'Alī al-Zayla'î reporting the position of the Hanafí school states:

"The authorized position of the school is that sighting in one city is sighting for all. It will become incumbent upon the inhabitants of the Eastern hemisphere to confirm the month by sighting in the West. The majority of (Hanafi) elders do not consider the diversity of horizons so

\footnotetext{
${ }^{26}$ Al-Shawkānī, Nayl al-Awțār.

27 Shah, 'The Astronomical Calculations and Ramadan: A Fiqhi Discourse'.

${ }^{28}$ Kuwait Ministry of Religious Affairs and Awqaf, 'al-Mawsū'ah al-Fiqhiyyah (Encyclopedia of Fiqh)' (Kuwait: Ministry of Religious Affairs and Awqaf, 1992), 142.

29 'Abdullāh Ibn Ahmad al-Nasafi, Kanz Daqāìq fi al-Fiqh al-Hanafi (Beirūt: Dār al-Bașī, 2011), 219-20.

30 Zayn al-Dīn Ibn Ibrāhīm Ibn Nujaym, Al-Baḥr al-Rāiq Sharh Kanz al-Daqāiq (Beirūt: Dār alKutub al-'Ilmiyyah, 1997), 471.
} 
Abdulmajeed Bolade Hassan-Bello

much so that they require making up for a day of fasting if people of one locality fasted for thirty days and the other locality for 29 days." 31

Ibn Jusay from the Mālikī School said:

"The report of a sighting of Ramaḍān crescent in any locality is binding on others, whether the place of sighting is close or far from them. Thus, those who have not seen the new Moon come under the ruling of those who have seen it." 32

Ibn Qudāma from Hanbalī School said: "If the crescent of Ramadān is sighted in any locality fasting become binding on the rest of the localities." $33 \mathrm{Al}-$ Bahūtī explains the Hanbalī positions:

"The Muslim world in its entirety is required to commence fasting by the report of sighting anywhere in the world whether the place of sighting is close or far from them. The ones who have not seen the new Moon come under the ruling of those who have seen it even if the horizons are different. Ahmad said that the noon (zawāl) all over the world is the same as the Prophetic commandment states: "start fasting by seeing it". It is directed to the entire Muslim community." 34

The basis for this doctrine is the Quran and numerous Prophetic traditions:

1. فمن شهد منكم الشهر فليصده "Therefore, whoever of you sights (shahida / شهد أشهد) the month, let him fast it" (al-Baqarah: 186)

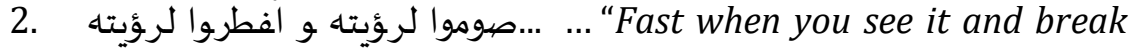
yoür fast when yoü see it".35

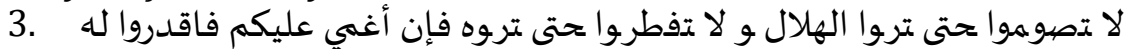
... ..."Do not fast üntil you sight the crescent and do not break (end) the fast until you sight it". 36

4. نحن أمة أمية لا ذكتب و لا نحسب... "We are an unlettered nation. We do not write nor count. The month is like this and like this...."37

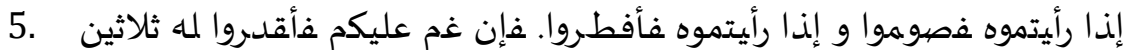
○. . يومان....If you sighted it, then fast; if you sighted) it, then break

31 Al-Zayla'̂̀, Tabyīn al-Haqā'iq Sharh Kanz al-Daqā'iq; 'Ābidīn, Radd al-Mukhtār 'alā Durr alMukhtār.

32 Muhammad Ibn Aḥmad Ibn Jusay, Qawānīn al-Fiqhiyyah (Beirūt: Dār Ibn Hazm, 2013), 212.

33 Muḥammad Ibn 'Abdullāh Ibn Qudāmah, al-Mughnī (Riyāḍ: Dār 'Alam al-Kutub, 1997), 328.

34 Manșūr Ibn Yūsūf al-Bahūti, Kashshāf al-Qinā' 'an Matn al-Iqnā', vol. II (Beirūt: Dār 'Alam alKutub, 1983), 303.

35 ‘Abd al-Wahhāb al-Sha'rānī, Kashfal-Ghummah (Cairo: Dār al-Fikr, 1969), 249.

36 'Shahih Muslim', n.d.

37 'Shahih Muslim, Shahih Bukhari and Ibn Majah', n.d. 
(end) the fast; and if your vision is obscured then (uqdurū lah / أمدة (أقدروا له

6. 7. 7. أكملوا المعدة ثثلاثين "..."Complete the counting to thirty (days)".39

These early jurists interpreted the hadīth "start fasting by sighting it and stop fasting by sighting it" as a universal command obligation Muslims all over the globe to fast Ramaḍān with trustworthy sighting in any locality.40

Despite such strong early positions, the later jurists roundly rejected the unity of horizon positions officially adopted by their schools. Al-Qarrāfī, Mālikī authority opined that since the crescent Moon differs with the difference in horizons, then it becomes incumbent that each locality must go with its own Moon (sighting). Obligating global fasting with local Moon sighting is far from the (established Islamic) rules. One needs to know that the (Islamic) texts did not require such an obligation. ${ }^{4}$

Similarly, other Scholars who approve of this opinion also differed on the matter. Some scholars said that when we say Global moon sighting, we mean the whole globe while others said that this is not the case. According to the latter, global moon sighting does not mean the whole world; it means regions or countries that are relatively close to one another or at least share a standard portion of the night. Some scholars have also narrated scholarly consensus that if the countries are as far as Andalus (Spain) and Khurasan (Iran), then they should be considered different regions. Ibn 'Abd Al-Barr said in his book AlIstidhkār: "The scholars have agreed that sightings of the crescent in countries that are as far away- as Andalus and Khurasan-should not be considered (for one another)." 42 This scholarly consensus, however, is controversial and there is a lot of discussion on the matter. Another opinion is that sighting of the crescent in any country becomes binding on all countries west of this country, but not the opposite. So a sighting of the crescent in Egypt would be binding to Morocco but not to Saudi Arabia. ${ }^{43}$

\footnotetext{
38 'Shahih Muslim'.

${ }^{39}$ Shah, 'The Astronomical Calculations and Ramadan: A Fiqhi Discourse'.

40 Shah. "The Astronomical Calculations," p. 11.

${ }^{41}$ Aḥmad Ibn Idrīs al-Qarrāfí, Anwār al-Burūq fi Anwā' al-Furūq, vol. IV (Kuwait: Dār al-Nawādir, 2010), 143.

${ }^{42}$ Abī 'Umar Yūsūf Ibn 'Abd al-Barr, Al-Istidhkār al-Jāmi' li Madhāhīb Fuqahā' al-Amșār, vol. X (Aleppo: Dār al-Wagha, 1993), 30.

43 El-Banna, 'Moon Sighting Explained'.
} 
It is observed that scholars differed in opinion between global and regional sighting and their respective variants, throughout the history of Islam; this decision was left to the Imam. Each Imam or Islamic governor in every region chose one of the two opinions whether (Global or Regional sighting), and everyone under his authority obeyed. And keeping in mind that the advance in telecommunications only took place recently, it was mostly Regional sighting or at least limited Global sighting that was practised. Even today the majority of Muslim countries (that depend on physical sighting) choose the Regional sighting opinion due to its practicality.44

\section{Mecca time-point for reference}

Head of Ahmadiyya Muslim jama'at Mirzā Nāșir Aḥmad in his sermon delivered at Rabwah on 27, January 1972 declared that beginning of the day should initiate from Mecca and that the world of Islam should mutually cooperate in this behalf. He, therefore, declared that all the brethren who ascribe to the Prophet Muhammad and are reliable as a witness and are truthful in their worldly dealings and choose righteousness, their sight of the moon in Mecca, shall be treated as acceptable. As aforesaid, by it, all Ahmadiyya community in the world shall observe the Eid el-Adha the same day as it shall be celebrated in the holy city of Mecca. ${ }^{45}$ Twenty-eight years later, his successor, Mirzā Tāhir Ahmad ruled that the date of Eid el-Adha is $10^{\text {th }}$ of Dhū al-Hijja of any country and therefore there is no question of celebrating it on any other day. According to this opinion if the crescent is physically sighted within the boundaries of a country, then the lunar month has started. Any reports of sighting that come from outside the boundaries of the region are irrelevant and do not affect their $10^{\text {th }}$ of Dhu al-Hijja. This verdict was given on April 32000.46 There is no contradiction between the two leaders. Nāșir Ahmad used discretion as to the head of the community, while Taahir Ahmad followed the general principle of regional moon sighting. According to this principle, if the crescent is physically sighted within the boundaries of a particular region, then the lunar month has started.

\footnotetext{
${ }^{44}$ El-Banna.

45 Mirza Nasir Ahmad, 'Mecca Point for Future Reverence', The Review of Religions LXVII, no. 5 (1972): 135-37.

46 Muhammad Mahmud Maishanu, 'Celebrating Eid-El-Azha', The Truth LI, no. 1 (2000): 1-8.
} 
Some Muslim individuals and organizations repeatedly call Muslims in the UK and some other non-Muslim countries to abandon following Saudi Arabia in determining Ramadān, Eid and Hajj. A section of these voices is driven by specific agendas to attack the Saudi government and ultimately to attack the religious ideology adopted by Saudi Arabia. In any case, they are unable to provide a practical and workable alternative. The suggestion for Muslims in the UK and other European countries to establish their moon-sighting has proven over the years to be both an impractical and a non-approachable solution for numerous reasons, including the fact that 47

They are unable to agree on one organization to represent them in this issue due to their vast and diverse nature. They differ on the course to be followed in case of failure to sight the moon on the possible dates of visibility; some recommend following astronomical data, others recommend following the sighting of the nearest Islamic country. They differ between themselves on which country to follow. ${ }^{48}$ Others suggest that when the moon is not sighted then, Sha'bān should be completed as thirty days irrespective of the astronomical data as this is mentioned in the Prophetic guidance. However, this recommendation is not widely accepted as it means that for the most part, Ramaḍān will start after the thirty days of Sha'bān due to the cloudy conditions in most European countries, including Britain. ${ }^{49}$

Another opinion put forward is for each Muslim to follow one's local mosque; this is the worst recommendation as it divides Muslims on a matter which should unite them as a single community; what does one do if there are two local mosques? Another option is to follow the first country that announces the sighting; while this is a very logical and legitimate opinion; it is unlikely to be accepted due to the political climate, diversity and disunity of Muslims living in the UK as an example. Moreover, those supporting astronomy as their basis will again question the sighting if it does not meet their criteria. ${ }^{50}$ However, almost two-thirds of the Muslims in the UK, USA and many countries of the world follow Mecca and not Saudi Arabia ideology; their

\footnotetext{
47 Haitham Al-Haddad, 'An Insight Into Moon-Sighting', n.d.

48 Al-Haddad.

${ }^{49} \mathrm{Al}$-Haddad.

${ }^{50} \mathrm{Al}$-Haddad.
} 
attachment is to Mecca as their holiest place and not to Saudi Arabia as a country. 51

\section{The four Sunni Schools on Astronomical Calculation}

Al-Sarakhsī, a leading Hanafi jurist, argued against calculation on the basis that astrologists and fortunetellers did it.52 Ibn 'Abidīn from Hanafi School established that the four schools of thought correct opinion are that there is no significance in the statements of the munajjimin (those who calculate astronomically)."53 In his commentary, he said: "there is no significance to the statements of almowakkiteen, i.e., those who calculate astronomically meaning in the obligation offasting". 54

Among the Mālikī school, Al-Dardīr said: "The start of Ramadān is established... either by completing the month of Sha'bān thirty days ... not by Astronomical Calculations according to the Mashhoor (the famous verdict in the Māliki school)".55 Zarrouk, in his commentary on Risāla Ibn Abī Zayd, said: "It is apparent from his words that no attention should be given to those who follow astronomical calculations, and this is the truth".56

From al-Shā'fi'̄ school, al-Nawāwī said: "Whoever approves of following Astronomical Calculations his opinion is rejected by the Prophet's Hadith "Fast when you see it and break your fast when you see it.". Haytamì said: "Fasting in Ramaḍan becomes compulsory through completing Sha'bān or the sighting of the Crescent... not according to an astrologer... or a Hāsib (one who calculates)... and it is not permitted for anyone to follow them".57 Al-Rashīdī said:" The legislator made fasting compulsory on us by physical sighting not just the mere

\footnotetext{
51 Al-Haddad.

52 Muḥammad Ibn Aḥmad Ibn Abī Sahl al-Sarakhsī, Al-Mabsūṭ, vol. III (Beirūt: Dār al-Ma'rifah, n.d.), 78.

53 ‘Ābidīn, Radd al-Mukhtār 'alā Durr al-Mukhtār.

54 ‘Ābidīn.

55 Sīdī Ahmmad al-Dardīr, Sharh al-Kabīr 'alā Mukhtașar Khalīl, vol. IV (Cairo: Dār Ihyā' al-Kutub al 'Arabiyyah, 1981), 509.

56 Ahmmad Ibn Muhammad Zarrūq, Sharḥ Zarrūq 'alā Matn Risālah Ibn Abī Zayd (Beirūt: Dār alKutub al-'Ilmiyyah, 2006), 436.

57 Ahmad Ibn Hajar al-Haytamī, Tuhfat al-Muhtaj bi Sharḥ al-Minhāj, vol. III (Cairo: al-Maktabah alTujjāriyah al-Kubrā,n.d.), 273.
} 
existing of the month's crescent." $58 \mathrm{Al}-\mathrm{Ramli}$ also said: "We can also understand from the words of the author (Al-Nawāwi) that the sighting of the Crescent can be established by sighting even if Astronomical Calculations state that there is no possibility of sighting... because the legislator (Allah and His Prophet) did not depend on Astronomical Calculations but ignored it, and this is the truth".59 Similarly, Al-Khațib al-Shirbinī, affirmed: "Fasting is not mandatory if the sighting of the crescent is based on Astronomical calculation."60

From Ḥanbalī School, Ibn Muflih said: "Whoever fasts according to astrology or astronomical calculations his fasting is invalid, even if he turns out to be correct, and no confirmation of sighting should be based on either, even if they are usually correct." 61 Ibn Qudama said: "And if someone depends on the statements of astrologers and those who know calculation, and it turns out that he was right, his fasting is invalid, even if they are usually correct because it is not a legal proof that one can depend on, or act upon, so its presence is equal to its non-presence."62

Muslims in North America do not use a lunar calendar for other than devotional purposes and have, in the past, had recourse to various methods of determining the lunar months. Recently, some leaders within the Muslim community have decided that it would be much better for Muslims to rely on the calculation to facilitate the start dates for people's scheduling concerns as well as the Eid dates for holidays with the hope that this will help the community gain recognition from the government for Muslim holidays, which would need to be known in the previous year when calendars are prepared. Some financial concerns are also mentioned. And finally, the importance of Muslim unity is cited as a reason for relying on the calculation to predetermine the lunar calendar, ${ }^{63}$ Given that the community seems split on the subject

\footnotetext{
${ }^{58}$ Aḥmad Ibn 'Abd al-Razzāq al-Rashīdī, Hāshiyah Rashīdī 'alā Nihāyah al-Muḥtāj, vol. III (Beirūt: Dār al-Kutub al-'Ilmiyyah, 2003), 150.

59 Aḥmad Ibn Hamzah al-Ramlī, Nihāyah al-Muhtājj, vol. III (Beirūt: Dār al-Kutub al-'Ilmiyyah, 2003), 153.

${ }^{60}$ Muhammad al-Khațīb al-Shirbīnī, Mughnī al-Muhtājj, vol. II (Beirūt: Dār al-Kutub al-'Ilmiyyah, 2000), 141.

${ }^{61}$ Shams al-Dīn Ibn Muḥammad Ibn Mufliḥ, Al-Furū'(Riyāḍ: International Ideas Home, n.d.), 611.

${ }^{62}$ Qudāmah, Al-Mughnī.

63 'Astronomical Calculations for Islamic Dates', n.d.
} 
every year. ${ }^{64}$ To address these genuine concerns, the Islamic Society of North America (ISNA), working with its Fiqh Council and some highly qualified mathematicians and astronomers, has decided that Muslims in North America should follow lunar months determined by calculation. They argue that astronomical science is highly developed and visibility charts can be generated to high degrees of precision; it is not against the Sunnah, as some scholars of the earliest period have accepted calculations as well as others of the later period; and many modern scholars are inclining toward this position in larger numbers. ${ }^{65}$

They further explained that Sighting the Hiläl (ru'ya) is not an act of 'ibāda in itself; it is instead a means to know with certainty about the beginning of the new month related to Islamic 'ibäda. And that ru'ya as a means was indicated and used by the Prophet -peace be upon him- because he said that the Ummah at that time was not literate and did not know how to write or to calculate (complex astronomical data). In the past, some classical jurists refused to allow calculations in this matter because in their time astronomy and astrology were not quite distinct sciences. Jurists were suspicious that astronomical predictions may not be based on exact science but whims, conjectures, superstition etc. Meanwhile, using calculations in determining the Islamic dates are not against the Sunnah. And reliable astronomical methods are now available to provide a sound basis for the determination of the Islamic dates of Ramadiān and the two 'ids. More importantly, Sharia is based on ease and considers the convenience of people. Thus, the announcement of Islamic dates ahead of time will reduce a lot of hardship, chaos and confusion that happen every year at the time of the beginning of Ramadān and the two Eids. ${ }^{66}$

In response to this announcement, some of the imams of North America announced their rejection of ISNA's decision substantiating their position from the perspective of Islamic law. They held that the ruling is based on the Hadith șümū li ru'yati which requires physical sighting of the moon. Harj was only cited as one of the possible wisdoms and rationale behind basing the ruling on the actual sighting. Therefore, irrespective of the existence of Harj (for which

\footnotetext{
64 Yusuf, 'Cesarean Moon Births'.

65 Yusuf.

66 'Astronomical Calculations for Islamic Dates'.
} 
one will be significantly rewarded) or not, because the fundamental requirement of actual sighting is proven from the hadith, this ruling can never be changed. The attempt to prove that ru'ya (sighting) is not an 'ibādāt in itself and that this should not be understood literally. And that Muslims rely on astronomical calculations for șalāt times without physically observing the sunset, sunrise, etc. For ifțār and saḥür purposes, one is not required to observe the dawn signalling the commencement of fasting physically. Supporting arguments with various verses of the Qur'an and hadith which contain variables of the word ru'ya in which context it does not constitute physical observance. He contends that being sure of the precondition being found is sufficient and one needs not physical observance thereof. ${ }^{67}$

In response, they held that any person possessing an elementary understanding of Ușül al-Fiqh will know that the literal meaning of a word must always be adopted. One may only move away from the literal meaning of the word if it cannot be applied in the context of the scenario in question. ISNA cited examples where the literal meaning cannot be applied, thus necessitating another meaning to be adopted. In the hadīth, șümū li ru'yati the literal meaning of the word can be applied and therefore, one may not adopt any other meaning. Physical observance of the crescent is not an 'ibādāt in itself. However, it is a precondition for the commencement of the month. For șalāt times as well as the dawn signalling commencement of the fast, physical observance is not a precondition. Once the precondition is found, e.g. sunset, Shawwāl, etc. and one is sure thereof, this is sufficient irrespective of whether it was observed physically or not. However, in the case of the crescent, the physical observance is a precondition in itself, and surety only is not sufficient. While astronomical calculations can predict exactly when a new moon will be born, but they cannot predict precisely when it can be seen. Thus, these calculations can tell you when it is impossible to sight the moon and when it is most likely to sight it. The popular view among Muslim jurists regarding the meaning of the Hadith "Fast upon sighting it (the crescent)..." is an actual sighting of the crescent. Therefore astronomy should be used to check sighting errors and complement actual sighting rather than replace it.

\footnotetext{
67 'Astronomical Data and Ramadhan', n.d.
} 
Turkey's state-run Presidency of Religious Affairs (DIB) President Mehmet Görmez opines that in this day and age when people can travel to the moon and observe the movements of sun and moon second by second, in this age of significant scientific developments, it was wrong to disregard these developments and insist on observing the new moon with the naked eye by climbing up mountains. Based on this fact, the International Hijri Calendar Union Congress convened in Istanbul for an event hosted by (DIB) "between" 28 to May 30, 2016, with the hope of adopting a single Islamic lunar calendar regarding the observance of religious holidays and especially concerns the fasting month of Ramaḍān and Eid al-Adha. Scholars from Saudi Arabia, Malaysia, United Arab Emirates, Morocco and nearly 50 countries attended the landmark congress which hosted a similar event in 1979, only to see an agreement to reach a unified calendar fell apart in the following years. This time the majority of scholars agreed on a single calendar. With this agreement, Görmez was very optimistic that the meeting has put an end to "a 60-year-old debate, but that had not happened.68

However, the guiding principle for the masses, therefore, is mentioned in the hadith, "the fast is the day you all fast; the breaking of fast is on the day that you all breakfast; and the day of sacrifice is on the day that you all sacrifice." $69 \mathrm{Al}-$ Tirmīdhì said, 'Some scholars explained this hadith to mean that fasting and breaking the fast should be done with the Muslim body jama' $a$ or the majority of people. ${ }^{70}$ This means that the ordinary person does not have his sighting of the moon or follow his own decision. The matters of beginning Ramadān and confirming Eid are not private affairs; they are decisions which affect the Muslim community and therefore have to be taken on that level. None can do this except the leader of the Muslims. When there is no leader, then the majority of Muslims represent the opinion of the community. ${ }^{71}$ Today, the same ruling should be applied on all sections or communities of Muslims due to the nature of Muslim countries being separated and each making its own

\footnotetext{
68 'Islamic Scholars Agree on a Shared Lunar Calendar for Muslim World', n.d.

${ }^{69}$ Ahmad Ibn al-Ḥusayn al-Bayhaqī, Sunnan al-Kubrā, vol. V (Beirūt: Dār al-Kutub al-'Ilmiyyah, 2003), 286.

70 Abū 'Īsā Al-Tirmīdhī, Sunan al-Tïrmīdhī, vol. II (Beirūt: Dār Gharb al-Islamī, 1996), 74.

${ }^{71}$ Abū al-Hassan Nūr al-Dīn al-Sanadī, Hāshiyah al-Sanadi 'alā Sunnan Ibn Mājah, vol. I (Beirūt: Dār al-jil, 1998), 509.
} 
decisions. Therefore, the Muslim individual is left with no choice but to go with the flow of the majority on this matter and to act according to the meaning of this hadìth.72

\section{The moonsighting dilemma in Nigeria}

In Nigeria, over four decades, there was instituted an organized system of sighting the crescent of the new moon associated with the Muslim religious rites of fast and Hajj in Nigeria. Emirs or religious leaders all over the country are mandated to be on the lookout for the moon heralding the beginning of the month-long Ramadān fast. Whoever in an Emirate sighted the moon is to report such with proofs to the Emir who in turn contacts the Sultan of Sokoto who collates such information for the former announcement to the nation through the media for the commencement of the short or end of same. This is done with all fear of God that there are very few instances whereby a diversity of sources do not corroborate the official sighting, and there are many towns and few villages that are not officially announced but are known locally to have seen the new moon on the announced time. 73

However, uninformed ignorant few under their imams insist on seeing the moon physically and end up starting the fast, in instances, two or three days behind the generality of people. Towards the end on the nineties, a new dimension has cropped up. Years back, the former Sultan authorized putting forward the date of Eid el-Adha by one day to avoid it is being celebrated on the same date as Arafat day in Saudi Arabia. There were heated debates and raised doubts that in that event questioned the validity of breaking the fast and observing Eid el-Fitr. It has also thrown a spanner in the works of diligent people who have been faithfully reporting the appearance of the crescent of Ramaḍān and Shawwāl over many years now. ${ }^{74}$

The year 2000 witnessed the other side of the coin. Nigerians began fast with Saudi Arabia, who is 2 hours ahead of Nigeria's time, but Nigerians did not break Ramaḍann fast with them. They broke it after 29 days, but even though many border countries to Saudi Arabia started and finished after 29 days with Nigeria while Saudi Arabia completed 30 days to finish a day later. Nigeria

\footnotetext{
72 Al-Haddad, 'An Insight Into Moon-Sighting'.

73 Abbas Femi, 'Eid Panorama', Vanguard, Friday, March 2001.

${ }^{74}$ Femi.
} 
celebrated Eid el-Fitr on Thursday, January 6, 2000. Counting two months and ten days (70 days) from thence brought Nigeria naturally to Wednesday, March 15, 2000, as the date of Eid el-Adha. The Sultan made a similar announcement and government declared Wednesday, 15 and Thursday, March 16 as public holidays. Paradoxically the same decision excited controversy and divided action. ${ }^{75}$ This issue is aggravated to the extent that a sharp difference is created between Nigeria and Saudi Arabia, thereby threatening the Unity of Muslims in Nigeria and the Muslim world at large.76 77

Previously, the endemic Ramaḍān and Shawwāl Moon Sighting Controversies were just centred on the announcement of the moon sighting by the Sultan of Sokoto and its opposition by a few 'Ulamä' and their followers. They insisted on sighting the moons themselves. But 2014/1435 AH year witnessed the most unfortunate incidence in the history of moon sighting in Nigeria, as the Secretary-General of the Nigeria Supreme Council for Islamic Affairs (NSCIA) and the Chairman of the National Moon Sighting Committee (NMSC) publicly opposed the National Broadcast confirming the sighting of the Shawwāl 1435 AH moon on Saturday, July 26 2014, by the NSCIA's President General, the Sultan of Sokoto. On Friday, July 25, 2014, when the Sultanate Council Sokoto issued a statement asking Nigerian Muslims to look out for the new moon of Shawwāl that would end the Fasting month of Ramaḍān on Saturday, July 26 2014, as that was the 29th day of Ramadān, 1435 AH in Nigeria. On that same Friday, the National Moon Sighting Committee (NMSC) set up by the Nigeria Supreme Council for Islamic Affairs (NSCIA), issued a canter message, that, Conjunction of Shawwāl Crescent is on July 26 2014, by $11.42 \mathrm{pm}$. Therefore it is impossible to sight it, that means we have no choice but to complete 30 days because conjunction is after sunset on 29th of Ramad̄ān. ${ }^{78}$

Again, the Secretary-General of the NSCIA, Professor Is-haq Oloyede issued a Press Statement as follows:

\footnotetext{
75 'Muslims Advised on Dates of Festivals', The Punch, March 2001.

${ }^{76}$ Qasim, 'The Position of Salatul-Id- Al-Adha in Nigeria on Arafat Day in Saudi Arabia'.

77 Qasim, “The Position of Salatul-id," p. 458

${ }^{78}$ Sani Abu Bakar Lugga, Moon Sighting Controversies (Kofar Marusa Katsina: Lugga Press Ltd, 2014), 9.
} 
It is an indisputable fact that the old (Ramadān) moon will set just before sunset in Nigeria on Saturday, July 26 2014. The new astronomic moon would be born a few minutes before midnight of that Saturday. Consequently, the search for Shawwāl moon is on Sunday, July 272014. It can be sighted in Nigeria on Sunday with optical instruments or with some difficulty with naked eyes. Any claim of sighting a moon that is yet to be born is not only false, mistaken, or impossible but also ridiculous. ${ }^{79}$

Oloyede did not deny the press report; therefore, it was taken as having come from him. Inadvertently. The controversy was most unnecessary as the NSCIA Secretary-General and the NMSC Chairman are highly enlightened and know very well that some instances of astronomers' forecasts that the moons of Ramaḍān and Shawwāl will not be sighted on some specific days in the United Arab Emirates, Saudi Arabia and Jordan; and the moons were sighted on those specific days! Moon Sighting \& Prayer Times Website on the Internet, posted its forecasts for the Shawwāl $1435 \mathrm{AH}$ moon sighting and had this under its Sunday, July 27, 2014, column:

Moon is not expected to be seen in almost the whole World except with difficulty in South America, and with ease in the Polynesian Islands, where there are not many Muslims reporting moon sighting. There is a slight possibility in South Africa, but only experienced observers may see it.

This forecast clearly states that even on Sunday, July 272014 (Eid Day in Nigeria), the Shawwāl 1435 moon was not expected to be sighted anywhere in the World except in South America and South Africa and even there it will be sighted "with difficulty". But, the same Website reported that the Shawwāl1435 moon was sighted in all the Regions of the World on that Sunday, July 27, 2014, and that the Eid was observed the following day (Monday, July 28) in 81 Countries. ${ }^{80}$ A representative sample per World-Region of the Countries where the moon was sighted on Sunday, being their 29th day of Ramaḍān (just as it was sighted on the 29th day of Ramaḍān in Nigeria) included Saudi Arabia, Qatar, Yemen, United Arab Emirates (Arabia); Niger Republic, Chad, Cameroons (West Africa); South Africa, Kenya, Malawi, Madagascar (South Africa); Egypt, Algeria (North Africa) Indonesia, Malaysia, Thailand (Asia); the United Kingdom, Spain (Europe); Barbados, Chile, Argentina (South America).

\footnotetext{
79 'Controversy in Nigeria over Sighting of New Moon to Mark End of Ramadan July 27, 2014', Premium Times, n.d.

80 Lugga, Moon Sighting Controversies.
} 
And despite the Nigerian cloudy raining season weather and the National Moon Sighting Committee's computer-generated imageries, estimations, calculations and forecasts; and the NSCIA Secretary General's negative statement, the new moon of Shawwāl 1435 AH was sighted on Saturday, July 26 2014, in 42 Towns and Cities spread over 17 Emirates, in 5 North East States, 5 North West States and 1 North Central State (eleven States). But it was not reported to have been sighted in the three Southern Nigeria's geo-political zones, particularly the South-West where Muslims are in the majority. That was because the Northern Zones disregarded the postulations of the NMSC Astronomers and went ahead to look out for the new moon. At the same time, those in the Southern Zones believed the astronomers' forecasts and did not lookout for the new moon. If they did, perhaps it would have been sighted there also. ${ }^{81}$ This assertion was confirmed by an Islamic Cleric and the Chief Imam of Ibara Housing Estate, in Abeokuta, the Ogun State Capital, Shaykh Fatai Opebiyi, on Sunday during his sermon after the Eid el-Fitr prayer held at Ibara GRA, Abeokuta. Said:

There was no need for any controversy over the sighting of the moon to commence or end the Ramaḍān fasting. The Muslim faithful should have faith in the ability of constituted authorities in the Nigerian Muslim Ummah to giving accurate information about moon sighting". He added that "Northern Muslims have established institutions for sighting the new moon unlike their counterparts from the South"... He also faulted the position of the Secretary-General of the Supreme Council for Islamic Affairs, Is-haq Oloyede, who, in an interview, directed Muslims to continue fasting on Sunday. The Imam concluded that "During Ramadān, Hausa people are in the desert looking for the moon while many of us preoccupied ourselves with other things in the South. ${ }^{82}$

Similarly, in 2015, the Nigeria Supreme Council for Islamic Affairs (NSCIA), has overruled the Jamaátu Nasril Islam, the umbrella body for Islamic organizations in Nigeria, on the declaration of Wednesday, September 23 Eid el-Adha day in Nigeria. The JNI had in a statement on Sunday by its SecretaryGeneral, Khalid Aliyu, said the month of Dhū al-Hijja begins today (Monday), meaning Eid el-Adha would be observed on Wednesday, September 23. The JNI, like the NSCIA, is under the leadership of the Sultan of Sokoto, Saád

\footnotetext{
81 Lugga.

82 Sani and Dimeji Kayode-Adedeji Tukur, 'Moonsighting Controversy: Islamic Group, Ogun Cleric Pass Votes of Confidence on Sultan', The Online Premium Times Newspaper, July 2014.
} 
Abubakar. When Premium Times contacted the Secretary-General of the NSCIA, Ishaq Oloyede on Monday, he said the announcement by the JNI was made in error. "The NSCIA would state on the new month of Dhū al-Hijja later today," he said. He also said the Moon-Sighting committee of the NSCIA already agreed with the decision of authorities in Saudi Arabia that the month of Dhū al-Hijja begins tomorrow (Tuesday). "Consequently, Eid el-Adha would be observed on Thursday, September 24, while Wednesday is Arafat day," he said. Sunday's statement by the JNI quoted the Sultan as 'felicitating' with Nigerian Muslims "over the successful commencement of Dhū al-Hijja today Monday, September 14 2015. This is indeed gratifying as Wednesday, September 23, 2015, will mark this year's Eid el-Adha, In Shā’a Allāh".83

Information gathered from all over the country showed that the Sultan's directive was fully complied with in all regions except the South West and Kwara State where compliance was put at 48 per cent. Of the few in the South West that complied, Akure Muslim Community under the leadership of Shaykh Abdul Hakeem Yayi Akorede and the rest, Ondo State Muslim Community complied and prayed on Sunday based on the directive of the Sultan. Akorede, during the Eid session, warned against defying the leadership of the Sultan especially over the issue of moon-sighting, adding that it was equivalent to sinning against Allah because, he said, "It is a sin to fast today (Sunday) that is Eid day."84

More worrisome to many was the allegation that Yoruba members of the NMC excluding the NMC national secretary, 'Abdullāh Shu'ayb, held a meeting in an undisclosed venue in Ibadan on the day Nigerian Muslims are supposed to be observing the Eid el-Fitr. When contacted, one of them, Dr K. K. Olosho, said, "We are in a meeting now. But I must tell you that there is fasting today (Sunday) and so tomorrow (Monday) is Eid el-Fitr." Vanguard's photojournalist, who was at the Obalende, Lagos Praying Ground on Sunday to cover the Eid prayer, found no one as he said the gates to the grounds were under lock and key, meaning that the Lagos Muslim Council did not comply with the Sultan's directive. Also, 'Abd al-Rahmān Ahmad, it was gathered, failed

\footnotetext{
83 Sani Tukur, 'NSCIA Overrules JNI, Says Eid-El-Kabir Day Is September 24, Not September 23 September', The Online Premium Times Newspaper, September 2015.

${ }^{84}$ Ishola and Bashir Adefaka Balogun, 'Eid-Ul-Fitri Moon-Sighting Controversy: How Conflicting Opinions Split the Ummah', Vanguard Newspaper, August 2014.
} 
to lead his congregation (Ansarudeen society of Nigeria) on that Sunday as directed by the Sultan. Ahmad is said to be a member of the13 Yoruba on the NMC set up by the Sultan. .5

In flagrant disobedience to the President-general, the Nigeria Supreme Council for Islamic Affairs and Sultan of Sokoto, His Eminence, Alhaji Muhammad Abū Bakr Sa'ad III, the Council of Chief Imam of Ibadan Land has ordered that Tarāwīh be prayed tonight, saying Ramaḍān commences tomorrow, Thursday, April 23, 2020. Muslim News had earlier reported the Sultan's message to Nigerian Muslims, urging them to search for the Crescent of Ramadān tomorrow, Thursday, April 23, 2020. However, a letter signed by the Chief Imam of Ibadan Land who also doubles as the Grand Patron of the League of Imams and Alfas of Yorubaland, Shaykh AbdulGanniy Abubakry Agbotomokekere announced Thursday, April 23 as the beginning of Ramaḍān fast. The statement read, "This is to inform the entire Muslim Ummah that (sic) the commencement of Tarāwĭh (Asamu) today Wednesday, April 22, 2020 equivalent to Sha'bān 29th 1441 and tomorrow Thursday, April 23, 2020, will be the first day of Ramaḍān 1441."86

Muslim News placed a call to the Chief Imam. Still, it was answered by his Assistant, Mr Idris Sulaiman, who confirmed that indeed, the letter emanated from the Council of the Chief Imam of Ibadan Land. He also emphasized that Ramaḍān commences tomorrow, Thursday, April 23, 2020, as Muslims are to observe Taraweeh at home this night in compliance to the COVID-19 lockdown. Asked of the modality used in concluding since tomorrow, Thursday is Sha'bān 29 based on the Sultanate counting, Mr Sulaiman said it was a matter of knowledge, adding that those with practical knowledge of moon sighting would understand that Ramaḍan commences tomorrow Thursday 23, 2020.87

The president of the Nigerian Supreme Council for Islamic Affairs (NSCIA) The Sultan of Sokoto Muhammad Abū Bakr Sa'ad III has declared Friday as the first day of Ramadān 4041AH, signifying the commencement of the annual long month fasting by Muslims. Abū Bakr made the announcement on

\footnotetext{
85 Balogun.

86 'Ibadan Council of Imam Defies Sultan, Observes Taraweeh', n.d.

87 'Ibadan Council of Imam Defies Sultan, Observes Taraweeh'.
} 
Thursday evening in Sokoto in a broadcast saying the moon has been sighted in some parts of the country and the reports of sighting of the new moon were received from Muslim leaders and organizations across the nation. ${ }^{88}$ The reports were duly verified and authenticated by the state and national moonsighting committee. Thus, the sighting of the new moon of Ramadān marks the end of Month Sha'bān 4041AH, the Muslims in Nigeria should, therefore, commence fasting accordingly. The Sultan of Sokoto Muhammad Abū Bakr Sa'ad III made the announcement on Thursday evening in Sokoto in a broadcast to the nation. ${ }^{89}$

A group, the League of Imams and Alfas of South-West Nigeria (Rabita alA'ïmma wa al-'Ulamā ), has said that this year's Ramaḍann will begin on April 25. The group said its picking of Ramaḍan date for Muslims to begin fasting was not meant to disrespect or challenge the authority of the Sultan of Sokoto, Muhammadu Sa'adu Abubakar III. In a statement signed by the group's Coordinator, Shaykh Muhammed Ḥabībullāh Adam EL-llory and two others, Assistant Coordinator, Shaykh 'Abd al-Razzāq 'Abd al-Azīz and Secretary, Moon Sighting Committee, Ustaz Nūr al-Dīn Ibrāhīm, the group insisted that it had been the practice since the league was formed in $1964 .{ }^{90}$

According to the group, the Holy Prophet had said: "Begin fasting when you sight the crescent and end the fast when you sight the crescent. However, if the crescent is obscure (not visible), then complete 30 days of Sha'bān.' (hadith)." The statement reads: "The League of Imams and Alfas of South-West Nigeria (Rabița al-A'imma wa al-'Ulamā') would like to inform the general public that Ramaḍān 1441/ 2020 commences on Saturday, April 25. "This is based on the findings of Islamic Sharia complemented with astronomical calculations. "Astronomically, the conjunction that leads to the termination of the month of Sha'bān 1441AH will occur on Thursday, April 23, (equivalent to 29th of Sha'bān, 1441AH) at 3:26 am in South-West Nigeria. "Thus, leaving the Age of the Moon (A.O.M), i.e. period between conjunction time and the next maghrïb (sunset time 6:54 pm) at $15 \mathrm{hrs} 28 \mathrm{mins}$, which is only enough for sighting the Moon by a powerful telescope or Binocular provided the weather is suitable. "It is also important to mention that the geocentric illumination for this

\footnotetext{
88 'Sultan Declares Sighting of Moon', n.d.

89 'Sultan Declares Sighting of Moon'.

90 'Ramadan Begins April 25, Says League of Imams and Alfas of South-West Nigeria', n.d.
} 
expected new crescent is $00.50 \%$, which will make sighting even with telescope still tricky. ${ }^{91}$

"Whereas, moon sighting with naked eyes is only possible when $17 \mathrm{hrs}-$ 23hrs elapse between conjunction time and the next maghrīb (sunset time). "However, based on astronomical findings, Ramaḍan will end on Saturday, May 23. This is because the conjunction that will terminate the month of Ramaḍann 1441 will occur on Friday, May 22, at 6:38 pm leaving the age of the Moon at Sunset $(6: 57 \mathrm{pm})$ at $+00 \mathrm{H} 21$ mins (i.e. sighting is not possible on the day). "Hence, the sighting of the crescent is only possible on Saturday, May 23, and Sunday, May 24, will be the official 1st day of Shawwāl, 1441AH."92

\section{Discussion}

The foundation of any legal ruling in Islam is the Qur'an and the verified Sunnah of the Prophet. All of the Qur'an and the Sunnah fall into four types: 1) An evidence that is decisive in its authentic transmission and also unequivocal in its meaning; 2) An evidence that is decisive in its authenticity but equivocal in its meaning; 3) An evidence that is of only probable authenticity but unmistakable in its meaning; 4) An evidence that is probable in its authenticity and equivocal in its meaning. Ijtihäd is not permissible in the first category. For instance, the texts that prescribe fasting are both authentic and unequivocal; therefore, no one can make a new ruling concerning the obligation of fasting and its time based on ijtihād. However, many texts, such as the majority of hadìth, are either probable (zanniyyāt al-wurūd) in the authenticity of their narrations or equivocal in their meanings (-anniyyāt al-dilalah); this accounts for the differences of opinions among the qualified and authoritative imams in many of their legal rulings. ${ }^{93}$ In the absence of decisively authentic and unequivocal texts, scholars may then and only then resort to ijtihād. Ijtihād is therefore employed only in the absence of a clear and authentic text and cannot be done otherwise. ${ }^{94}$

The second important rule to note about independent reasoning is that any ijtihād concerning ambiguous texts must conform with verified Arabic connotations as understood by the Arabs during the Prophet's lifetime and

\footnotetext{
91 'Ramadan Begins April 25, Says League of Imams and Alfas of South-West Nigeria'.

92 'Ramadan Begins April 25, Says League of Imams and Alfas of South-West Nigeria'.

93 Yusuf, 'Cesarean Moon Births'.

94 Yusuf.
} 
recorded in the accepted lexicons of the masters of Arabic lexicology. Hence, a thorough knowledge of classical Arabic as understood by the first generation of Muslims as well as of several other sciences is required before one can perform ijtihād. ${ }^{95}$

If we understand these foundational principles, we can now look profitably at the differences that arose about how we determine the onset of the two months of Ramadiann and Dhū al-Hijja, in particular, and the other lunar months in general. The Qur'an says, "They ask you about the crescent moons; say they are a means to measure your specific times and are also for the commencement of the hajj." (al-Baqarah: 189) This text is both decisive in its authenticity, because the entire Qur'an is decisively authentic (qați $a l-w u r u \bar{d}$ ), and it is decisive in its meaning because there is no ambiguity about what crescents (ahilla) mean in the Arabic language, and what the means to measure specific times (mawāqit) denote; hence, ijtihād is not an option. ${ }^{96}$

The Qur'an commands Muslims to use the crescent moons as a means for determining the lunar months and the sacred obligations of fasting in Ramaḍān and performing Hajj in Dhū al-Hijja. An important point to note about this verse is that it specifies Hajj and leaves Ramaḍān to be understood in the general meaning of the verse. According to the great commentators, Hajj was mentioned in preparation for the final prohibition on determining the Hajj based upon intercalation and not sighting, as the pre-Islamic Arabs sometimes predetermined Hajj, so they did not need to look for the moon during the Hajj season. al-Qurtubī comments: "what is numbered, counted, reckoned, or computed, ${ }^{97}$ And alteration of the months. Thus, God nullified their words and deeds. .98

Another verse commands Muslims to fast for the month of Ramadian, unambiguously the lunar month known to the Arabs at that time. The verse says, "The month of Ramadān is the one in which the Qur'an was revealed as a guidance for humanity and clarifications of that guidance and a standard. So whoever witnesses (shahida) the month among you, let him fast" (al-Baqarah:

\footnotetext{
95 Yusuf.

96 Yusuf.

97 Edward William Lane, Arabic-English Lexicon, vol. II (Cambridge: Islamic Texts Society, 1984), 1970.

98 Muhammad al-Anșārī al-Qurtubī, Al-Jāmi' li Aḥkām al-Qur'ān, vol. II (Beirūt: Maktabah al-Bāz, 1993), 229.
} 
185). Ibn al-'Arabī comments on this verse: "Month here actually referred to the crescent moon of the month and was called "the month" (al-shahr) due to everyone knowing of its arrival. ${ }^{99} \mathrm{Al}$-Tirmìdhì relates that the Prophet said:

"Note the day that the crescent moon of Sha'bān appears to determine Ramadān's crescent."100 This is reiterated in the Prophet's words, "Fast upon seeing it and break the fast upon seeing it. "And if the crescent moon is obscured, then determine it (faqdurū lah). ${ }^{101}$

But the actual meaning among the scholars of consummate expertise is "complete its number." This is why the Prophet said in another narration, "Complete the number of days of Sha'bān, thirty days." Furthermore, in another narration, he said, "If it is obscured, then complete a fast of thirty, and then break your fast". Some claimed that al-Shāfi'i said one could depend upon calculating, and this is a fall one cannot arise from. ${ }^{102}$ The Spanish master of the sciences of Islam, Ibn 'Abd al-Barr, says this about the same verse:

God says, "Whoever witnesses the month, let him fast" (Surah al-Baqarah: 185). He means, and God knows best, "Whoever among you knows, with a knowledge that is certain, that the month has indeed begun must fast it." And the specific knowledge is based on either sighting or the completion of thirty days of the previous month. ${ }^{103}$

The Sharia also allows the testimony of two just witnesses who saw the moon on the thirtieth night of Sha'bān. That is also sound, and therefore the previous month was of twenty-nine days. Some would consider this sound only if the sky was clear and [the crescent not sighted], which is the meaning of "if not, then determine it (faqdurū lah)" among the majority of scholars. ${ }^{104}$ According to Ibn Sirin, some of the great scholars among the second generation (täbi'in) understood it to imply a consideration of astronomy, the mansions of the moon phases, and mathematical calculation. Ibn Sirin said about this position, "It would have been better had they not done so." It is believed he was referring to Mutarrif bin 'Abdullāh bin al-Shikhir, and God knows best. Mutarrif

\footnotetext{
${ }^{99}$ Muḥammad Ibn Ja'far al-Kattānī, Nazm al-Mutanāthir min al-Hadīth al-Mutawātir (Cairo: Dār alKutub al-Salafiyyah, 1998), 129.

100 Al-Tirmīdhī, Sunan al-Tirmìdhì.

101 Yusuf, 'Cesarean Moon Births'.

102 Al-'Arabī, Ahkām al-Qur'ān.

103 al-Barr, Al-Istidhkār al-Jāmi' li Madhāhīb Fuqahā' al-'Amșār.

104 al-Barr.
} 
was among the great pious and second-generation patient scholars of Basra. ${ }^{105}$ Ibn Surayj also relates that al-Shāfî̀ said:

Whoever is schooled in the ability to determine the course of the stars and the mansions and phases of the moon, and it is clear to him from his knowledge that the crescent moon will appear on a given night, but then, clouds obscure it, then, in that case, it is permissible for him to consider it time to fast and sleep with the intention 'of fasting the next day', and he will be rewarded.106

However, what we have found authenticated in his books is that he considered the month of Ramadān to be valid only by a widespread sighting or sound testimony or completion of thirty days of Sha'bān by that Hadith "Fast when you see it and break your fast when you see it." This is the school of four famous Sunni. Abū Hanifah and his students, Mālik, al-Shāfi'ī, al-Awzā'ī, and all of the people of hadīth, except for Ahmad bin Hanbal and those who conferred with him. 107

It is clear that none of these men understood the opinion that allowed calculation to mean bypassing the actual sighting; instead, they understood calculation to be permissible only if atmospheric conditions obscured the visibility factor. Another important reason for rejecting the interpretation of the hadith, "and if it is obscured then calculate it" to mean the use of scientific measurements is that the other narration, "and if it, i.e. the new moon of Ramaḍān is obscured, then complete thirty days of Sha'bān." In uṣūl, this is known as mubayyin (clarifying), and the former is called mujmal (ambiguous). It is a well-known ușūli principle that if a hadìth has one narration that is equivocal and another that is unequivocal, and both are of equal authenticity, then the unmistakable is the one used for legislative purposes. ${ }^{108}$

Ibn Rushd clarified this matter and opined that the difference of opinion about the commencement of Ramadān results from the ambiguity in the hadīth, "Fast based upon its sighting and break your fast based upon it, and should it be obscured, then calculate it." But the majority of scholars took the other narration, which states "Complete the number of thirty days." Some of them said the measurement (taqdīr) mentioned in the first hadith means the

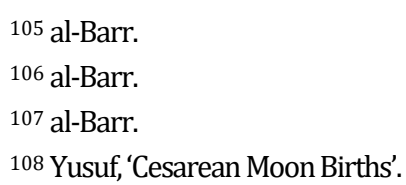


new month should be determined with the use of calculation, and others said it simply means that you should fast the next day, irrespective of what your calculations may lead you to conclude. The latter is the way of Ibn 'Umar. But the majority went with the authentic narration of Ibn 'Abbās, which states that the Prophet said, "And if it, i.e. the new moon of Ramaḍan should be obscured, then complete the thirty days of Sha'bān." And, since the former is ambiguous (mujmal) and the latter clarifying (mufassir), then it is an obligation (wajib) to interpret the ambiguous one by the one that clarifies. Besides, this methodology is one in which there is no difference of opinion among the scholars, especially given that the two narrations do not involve a contradiction. Hence, how the majority of the jurists have understood it is the correct one. ${ }^{109}$

Ibn al-'Arabī, in his commentary Al-Qabas fi Sharh Muwatța' Mālik bin 'Anas, opined that God has obliged Muslims to fast based upon the sighting of the crescent moon and added to that an injunction to note the commencement of Shawwāl's crescent. Also, here is an interesting juristic point: some of the scholars of the second generation said that if the crescent moon is obscured, one may use calculation. Thus, if an astronomer says, "Tonight, based upon the crescent's angle of elongation, it is normally possible to sight the crescent had it not been for atmospheric conditions," we can act according to his statement in our fasting and breaking of our fast based upon the Prophet's statement, "determine it." In other words, they argue that he meant, "Calculate the position of the moon" based upon God's word, 'We have fixed exactly the moon's phases' ...." (Al-Zumar, 39).

What a calamitous mistake they have made! We are not, of course, denying the foundation of the science of calculation nor of the discernable patterns of the mansions and moon phases. However, it is not possible that use of scientific calculations was intended in the meaning of the hadīth for two reasons: Firstly, Mālik discerned a principle in hadīth interpretation which became a basis for those who came after him. Mālik said that the first hadith is equivocal, but the ambiguity in it was clarified in the second hadith, in which the Prophet s said, "Complete the number thirty." In other words, the second hadīth clarifies what the first meant. As for the second reason, it is not permissible to rely on astronomers and mathematicians, not because their findings are not accurate

109 Abū al-Wālid Muhammad Ibn Rushd, Bidāyah al-Mujtahid wa Nihāyah al-Muqtașid (Beirūt: Dār al-Kitāb al-'Arabī, 2004), 228. 
but because people's beliefs must be protected from an association with celestial motions and future occurrences of conjunctions and separations. Indeed, that is a vast ocean should people be pulled into it. Moreover, there is a position, stated by people of understanding among the scholars of the second generation, that in the specific hadith in which the Prophet showed the number of days of Ramad̄an using his fingers, the Prophet negated the use of the common numerals that mathematicians use. Therefore, it is even more likely that he would negate the use of celestial bodies and their orbits. ${ }^{110}$

What we find profoundly interesting is Qāḍi Abū Bakr's point that the Prophet could very well have used the words "twenty-nine and thirty" when indicating the number of days possible in a lunar month. Had he done so, those he was speaking to would have understood him, as he was wont to state numbers on many other occasions as reported in sound hadith; he used high numbers, such as one million (alfu alf); he also used twenty-seven, twenty-five, and five; and he used the number ninety-nine in the sound hadìth, "God has ninety-nine Names, one-hundred less one; whoever enumerates them will enter Paradise." However, he chose not to state any numbers when showing the number of days in a lunar month, as if to deter people from thinking about enumeration specifically when it comes to determining the lunar months. Hence, instead of saying the words "twenty-nine and thirty," the Prophet s used his blessed hands, showing with his fingers how many days are possible in the month, as if to emphasize using the most basic human ability of sight. It is as though he were saying, "Look, see, perceive with your eyes the month, even upon my hands." This insistence upon sighting the moon illustrates so well "the sense in Islam that it is the immediate surrounding conditions, rather than any theoretical ones, that reflect the Divine will of God in its relation to men, and that it is these which should determine the sacred acts." 111

The Prophet commanded the Muslims to keep track of the crescent moons and to inform him when sighted. If a new moon was sighted for the devotional months of Ramaḍān or Dhū al-Hijja (the month in which Hajj is performed), the news was announced to all. In $637 \mathrm{CE}$, sixteen years after the Hijra of the Prophet, the caliph 'Umar instituted the new Islamic year based upon the first of Muharram in the year that the Prophet had migrated from Mecca to Medina.

110 Abū Bakr Ibn al-'Arabī, Al-Qabas fi Sharh al-Muwatțā' Mālik Ibn 'Anas (Beirūt: Dār Gharb alIslāmī, 1992), 483-84.

111 Cyril Glasse, The Concise Encyclopedia of Islam (San Francisco: Harper \& Row, 1986), 96-97. 
The first of Muharram 622 CE, which coincided with July 16622 CE, began year one of the Muslim eras. Muslim astronomers and mathematicians have maintained rigorous and practical calendars for their respective eras, developed accurate ephemerides that detail the phases of the moon, and even provided crescent visibility tables for different climes. ${ }^{112}$

This demonstrates that Muslims in pre-modern times did indeed possess the intricate and detailed knowledge necessary to construct both lunar and solar calendars to organize their worldly and religious affairs. ${ }^{113}$ Shortly after the collapse of the Ottoman Empire, non-Muslim colonialists ran the administrations of much of the Muslim world, which led to the Muslim adoption of the current Gregorian calendar. Despite the almost universal domination of the Western calendar, Morocco, the United Arab Emirates, Egypt, Turkey, and Saudi Arabia still produce qualified sacred timekeepers who have studied the traditional science of horology and are capable of maintaining lunar calendars based upon both separations (mufäraqa), as is currently practised in Saudi Arabia, and moon sighting, such as what is practised in Morocco. ${ }^{114}$

Thus, there is a near consensus among jurists that the criterion for the start of the Islamic month is for the new crescent to be visible in the sky; most jurists specify that it must be visible to the unaided eye (and not through a telescope or other instrument). Contrary to what some people think, this is different from the new moon, which is invisible from earth. The crescent usually becomes visible one or two days after the new moon.

Science and Technology are "knowledge-based", and Islam is based on and encourages the seeking of knowledge. Therefore, Muslims accept that Science and Technology could be used to assist in new moon sighting." However, the use of Science and Technology should be complementary and not an alternative to the paramount physical eye sighting of the moon. For example, suppose computer software-generated images suggest that a moon may not be sighted on a particular day. Still, Muslims testify (by the Sharia provisions) to seeing the moon with their eyes on that day. In that case, their testimony

\footnotetext{
112 Glasse, The Concise Encyclopedia of Islam.

113 Yusuf, 'Cesarean Moon Births'.

114 Yusuf.
} 
should override the computer-generated forecast and not the other way round. 115

In Nigeria, there is a need to understand the Sharia, and what it imposes on people. For a person resident in Nigeria, what is demanded of him is Eid alAdha and the Animal sacrifice on the day proclaimed to be the 10th of Dhū alHijja by his leaders by their new moon sighting, and not what Sharia demands of a pilgrim or someone resident in Saudi Arabia or any other country. More importantly, Sharia did not ask people to follow Saudi Arabia. Thus we cannot say that, those that went by the provisions of the Sharia and did what their leaders ordered them to do and by the provisions of the law, that their Eid prayers or sacrifices are vitiated. Had it been so, the Prophet would have made a categorical statement to that effect. Therefore when Nigeria and some countries in the World may celebrate Eid al-Adha on the 10th of Dhū al-Hijja which may not coincide with the Saudi authorities, it does not mean such Eid al-Adha is not in conformity with the Sunnah.116 Prophet said as quoted earlier "the fast is the day you all fast; the breaking of fast is on the day that you all breakfast; and the day of sacrifice is on the day that you all sacrifice".

\section{Conclusion}

The paper concludes that all the trends above, which have been prevalent among the Muslim scholarship throughout Islamic history, are acceptable as long as they do not lead to mutual discard and accusations of misguidance. All reflect the sincere efforts to implement the intent of the Lawgiver to the best of human abilities. Sharia has enough room for pluralism as long as the sincerity of intention, and the textual proof is guaranteed. The paper, therefore, opines that unity is of paramount importance and every attempt should be made to create a united Ummah, but this should never be at the expense of the teachings and practices of the Prophet. The commencement of the Islamic month is dependent on the physical sighting of the crescent (or completion of 30 days) as has always been the opinion of the vast majority of the Ummah. Astronomical calculations will not be rejected. They will be used to authenticate reports on the physical sighting.

\footnotetext{
115 Lugga, Moon Sighting Controversies.

116 Qasim, 'The Position of Salatul-Id- Al-Adha in Nigeria on Arafat Day in Saudi Arabia'.
} 
The paper opines that sighting the moon is an intended purpose of Ramadiann. The Prophet has commanded Muslim in a Hadìth that is of no less authority than the Qur'an itself: "Fast upon seeing the crescent, and break your fast upon seeing it; and if it is obscured, then calculate it." The meaning is exact, as has been clarified by the illustrious jurists quoted in this paper. Muslims are therefore advised not to accuse other Muslims, exceptionally knowledgeable people, of committing trivial mistakes concerning significant matters. It is established that Eid al-Adha is independent of 'Arafah because both are observed on different days. Therefore the observance of Eid al-Adha on 'Arafah day in any part of the world is allowed and accepted in Islam but preferably celebrating it with Saudi Arabia is the best if that is possible. However, the evidence compels Muslims to follow the opinion of the majority of Muslims in any country irrespective of how the opinion is arrived at. This diversity of opinions shouldn't lead to disunity. Unity and conformity are two separate things. Islam requires us to have unity amongst ourselves, not conformity. Ibn Majshoon has suggested the practical solution. This prominent Māliki jurist said that the regions should depend on the Imam's authority (head of Islamic state) so if the Imam announces the start of the lunar month, then all cities under his authority should accept it. And even with this, how the month is determined are contained in either sighting or completing thirty days. There is no room for reliance upon calculation.

However, controversy on moon sighting in Nigeria would continue as long as the country continues with politics of religion and religious politics. If not? Why are there conflicts between the Nigeria Supreme Council for Islamic Affairs (NSCIA), and its Secretary-General? What necessitates conflict between National Moon Sighting Committee (NMSC) and the body that set it up NSCIA? How do we explain the differences between Jamaátu Nasril Islam (JNI), with its president General? From another angle, the Chief Imam of Ibadan Land and the Grand Patron of the League of Imams and Alfas of Yoruba land openly disagreed with the League. The League announced this year's Ramadiann begins on April 25. Sultan announced April 24, while chief Imam of Ibadan land begins Ramaḍān on April 23 2020. The league though said its picking of Ramaḍān date for Muslims to begin fasting was not meant to disrespect or challenge the authority of the Sultan of Sokoto if that decision is not to disrespect the Sultan what does that constitutes? The paper, therefore, recommended the establishment of a Federal Ministry of Islamic religious Affairs to be in charge 
of moon sighting. By doing so, Nigeria Supreme Council for Islamic Affairs (NSCIA), and National Moon Sighting Committee (NMSC) would be under the Ministry and would be its employees.[a]

\section{BIBLIOGRAPHY}

'Ābidīn, Muhammad Āmīn Ibn. Radd al-Mukhtār 'alā Durr al-Mukhtār. Vol. III. Riyāḍ: Dār 'Alam al-Kutub, 2003.

Abadī, 'Abd al-Raḥmān al-'Aẓīm. 'Awn Al-Ma'būd Sharh 'alā Sunan Abī Dāwud. Beirūt: Dār Ibn Hazm, 2005.

Ahmad, Mirza Nasir. 'Mecca Point for Future Reverence'. The Review of Religions LXVII, no. 5 (1972): 135-37.

Al-'Arabī, Abū Bakr Ibn. Al-Qabas fi Sharh al-Muwaț̣ā' Mālik Ibn 'Anas. Beirūt: Dār Gharb al-Islāmī, 1992.

——_. Ahkām al-Qur'ān. Vol. I. Beirūt: Dār al-Kutub al-'Ilmiyyah, 2003.

'Astronomical Calculations for Islamic Dates', n.d.

'Astronomical Data and Ramadhan', n.d.

Al-Bahūtī, Manșūr Ibn Yūsūf. Kashshāf al-Qinā' 'an Matn al-Iqnā'. Vol. II. Beirūt: Dār ‘Alam al-Kutub, 1983.

Balogun, Ishola and Bashir Adefaka. 'Eid-Ul-Fitri Moon-Sighting Controversy: How Conflicting Opinions Split the Ummah'. Vanguard Newspaper, August 2014.

Al-Barr, Abī 'Umar Yūsūf Ibn 'Abd. Al-Istidhkār al-Jāmi' li Madhāhīb Fuqahā'al'Amșār. Vol. X. Aleppo: Dār al-Wagha, 1993.

Al-Barūsuwī, Ismāīl Ḥaqqī. Tanwīr al-Adhhān min Tafsīr Rūh al-Bayān. Vol. I. Damascus: Dār al-Qalam, 1988.

Al-Bayhaqī, Ahmad Ibn al-Ḥusayn. Sunnan al-Kubrā. Vol. V. Beirūt: Dār alKutub al-'Ilmiyyah, 2003.

'Controversy in Nigeria over Sighting of New Moon to Mark End of Ramadan July 27, 2014'. Premium Times, n.d.

Cowan, J. Milton, ed. The Hans Wehr Dictionary of Modern Written Arabic. New Delhi: Modern Language Services, 1994.

Al-Dardīr, Sīdī Ahmad. Sharh al-Kabìr 'alā Mukhtașar Khalīl. Vol. IV. Cairo: Dār Ihyā' al-Kutub al 'Arabiyyah, 1981. 
Abdulmajeed Bolade Hassan-Bello

Dukku, Usman H. 'Friday Discourse: The Problem of Moon Sighting in Nigeria: The Way Out', n.d.

El-Banna, Omar. 'Moon Sighting Explained', n.d.

Al-Farāhīdī, Al-Khalīl ibn Ahmad. Kitāb al-'Ayn. Vol. IV. Beirūt: Dār al-Kutub al'Ilmiyyah, 2003.

Femi, Abbas. 'Eid Panorama'. Vanguard, Friday, March 2001.

Glasse, Cyril. The Concise Encyclopedia of Islam. San Francisco: Harper \& Row, 1986.

Al-Haddad, Haitham. 'An Insight Into Moon-Sighting', n.d.

Al-Haytamī, Ahmad Ibn Hajar. Tuhfat al-Muhtaj bi Sharh al-Minhāj. Vol. III. Cairo: Al-Maktabah al-Tujjāriyah al-Kubrā, n.d.

'Ibadan Council of Imam Defies Sultan, Observes Taraweeh', n.d.

Ibn Manzuūr, Muhammad Ibn Mukram. Līsan al-'Arab. Vol. II. Beirūt: Dār alKutub al-'Ilmiyyah, 1993.

Al-Ișfahanāi, Abū al-Qāsim al-Husain al-Rāghīb. Al-Mufradāt fi Gharīb al-Qur'ān. Damascus: Dār al-Qalam, 1992.

'Islamic Scholars Agree on a Shared Lunar Calendar for Muslim World', n.d.

Jusay, Muḥammad Ibn Ahmad Ibn. Qawānīn al-Fiqhiyyah. Beirūt: Dār Ibn Hazm, 2013.

Al-Kattānī, Muhammad Ibn Ja'far. Nazm al-Mutanāthir min al-Hadīth alMutawātir. Cairo: Dār al-Kutub al-Salafiyyah, 1998.

Kuwait Ministry of Religious Affairs and Awqaf. 'Al-Mawsū'ah al-Fiqhiyyah (Encyclopedia of Fiqh)'. Kuwait: Ministry of Religious Affairs and Awqaf, 1992.

Lane, Edward William. Arabic-English Lexicon. Vol. II. Cambridge: Islamic Texts Society, 1984.

Lugga, Sani Abu Bakar. Moon Sighting Controversies. Kofar Marusa Katsina: Lugga Press Ltd, 2014.

Maishanu, Muhammad Mahmud. 'Celebrating Eid-El-Azha'. The Truth LI, no. 1 (2000): 1-8.

Muflih, Shams al-Dīn Ibn Muhammad Ibn. Al-Furū'. Riyāḍ: International Ideas Home, n.d.

'Muslims Advised on Dates of Festivals'. The Punch, March 2001. 
Al-Nasafi, 'Abdullāh Ibn Ahmad. Kanz Daqā’iq fi al-Fiqh al-Hanafi. Beirūt: Dār al-Bașīr, 2011.

———. Tafsìr al-Nasafi. Vol. I. Beirūt: Dār al-Qalam al-Ṭayyib, 1998.

Al-Nawawī, Abū Zakariyyā Muhyiddīn Yahyā ibn Sharf. Al-Majmü' Sharh alMuhadhdhab. Vol. VI. Jeddah: Maktabah al-Irshād, n.d.

Nujaym, Zayn al-Dīn Ibn Ibrāhīm Ibn. Al-Bahr al-Rā'iq Sharh Kanz al-Daqā’iq. Beirūt: Dār al-Kutub al-'Ilmiyyah, 1997.

al-Qarrāfī, Ahmad Ibn Idrīs. Anwār al-Burūq fi Anwā' al-Furūq. Vol. IV. Kuwait: Dār Al-Nawādir, 2010.

Qasim, Mustapha Isa. The Position of Salatul-Id- Al-Adha in Nigeria on Arafat Day in Saudi Arabia'. International Journal for Innovative Research in Multidisciplinary Field 2, no. 11 (2016): 458-61.

Qudāmah, Muhammad Ibn 'Abdullāh Ibn. Al-Mughnī. Riyāḍ: Dār 'Alam alKutub, 1997.

al-Qurtubī, Muhammad al-Anșārī. Al-Jāmi' li Aḥkām al-Qur'ān. Vol. II. Beirūt: Maktabah al-Bāz, 1993.

'Ramadan Begins April 25, Says League of Imams and Alfas of South-West Nigeria', n.d.

Al-Ramlī, Ahmad Ibn Hamzah. Nihāyah al-Muḥtāj. Vol. III. Beirūt: Dār Al-Kutub Al-'Ilmiyyah, 2003.

Al-Rashīdī, Ahmad Ibn 'Abd al-Razzāq. Hāshiyah Rashīdī 'alā Nihāyah alMuḥtāj. Vol. III. Beirūt: Dār Al-Kutub Al-'Ilmiyyah, 2003.

Rushd, Abū al-Wālid Muhammad Ibn. Bidāyah al-Mujtahid wa Nihāyah alMuqtașid. Beirūt: Dār al-Kitāb al-'Arabī, 2004.

Safi, Louay. 'Reading, Sighting, and Calculating', n.d.

Al-Sanadī, Abū al-Ḥassan Nūr al-Dīn. Hāshiyah al-Sanadi 'alā Sunnan Ibn Mājah. Vol. I. Beirūt: Dār al-Jīl, 1998.

Al-Sarakhsī, Muhammad Ibn Aḥmad Ibn Abī Sahl. Al-Mabsūṭ. Vol. III. Beirūt: Dār al-Ma'rifah, n.d.

Al-Sha'rānī, 'Abd al-Wahhāb. Kashf al-Ghummah. Cairo: Dār al-Fikr, 1969.

Shah, Zulfiqar Ali. "The Astronomical Calculations and Ramadan: A Fiqhi Discourse'. International Institute of Islamic Thought, 2009.

Al-Shawkānī, Muhammad Ibn 'Alī. Nayl al-Awțār. Vol. IV. Cairo: Maktabah Dār Turāth, 1965. 
Abdulmajeed Bolade Hassan-Bello

Al-Shirbīnī, Muhammad al-Khațīb. Mughnī al-Muḥtāj. Vol. II. Beirūt: Dār alKutub al-'Ilmiyyah, 2000.

Su'ūd, Muhammad ibn Mușțafā Abū. Irshād al-'Aql al-Sālim ilā Mazāyā alQur'ān al-Karīm. Vol. I. Beirūt: Dār Ihyā' al-Turāth al-'Arabī, 1994.

'Sultan Declares Sighting of Moon', n.d.

Al-Tirmīdhī, Abū 'Īsā. Sunan al-Tirmìdhī. Vol. II. Beirūt: Dār Gharb al-Islamī, 1996.

Tukur, Sani. 'NSCIA Overrules JNI, Says Eid-El-Kabir Day Is September 24, Not September 23 September'. The Online Premium Times Newspaper, September 2015.

Tukur, Sani and Dimeji Kayode-Adedeji. 'Moonsighting Controversy: Islamic Group, Ogun Cleric Pass Votes of Confidence on Sultan'. The Online Premium Times Newspaper, July 2014.

Yusuf, Hamza. 'Cesarean Moon Births', n.d.

Zarrūq, Aḥmad Ibn Muhammad. Sharh Zarrūq 'alā Matn Risālah Ibn Abī Zayd. Beirūt: Dār al-Kutub al-'Ilmiyyah, 2006.

Al-Zayla'̄, 'Uthmān ibn 'Alī. Tabyīn al-Haqā'iq Sharh Kanz al-Daqāíq. Vol. I. Beirūt: Dār al-Kitāb al-Islamī, 2009. 